\title{
Horizontal dorsal resection of a crooked septum in septoplasty
}

\author{
1, Hyun Jong Jeon ${ }^{2}$, Hyun Soo Lee ${ }^{2}$, Jae Woo Lee², Eun Jung Lee ${ }^{2}$, and Dong-Joon Park ${ }^{2}$ \\ ${ }^{1}$ Yonsei University Wonju Christian Hospital \\ ${ }^{2}$ Yonsei University Wonju College of Medicine
}

September 25, 2021

\begin{abstract}
Objective: There are several types of septal deviation, including horizontal, vertical, C-shaped, S-shaped, and high deviation. One of the most difficult of these types to correct is the crooked dorsal septum, which attaches to the upper lateral cartilage and causes a high septal deviation. We propose a method for horizontal dorsal resection of a crooked septum using a mucosal through-and-through suture technique for the correction of high septal deviation. Design and setting: The medical records of 30 patients $(27$ men) who underwent septoplasty by one author of this study from 2019 to 2020 at our institute were reviewed prospectively. The median follow-up was 11 months (range, 4-16 months). All patients underwent a horizontal dorsal septal cartilaginous resection with mucosal through-and-through suture. Data were collected on demographics, symptoms, anatomic site of deviation, and postoperative complications. Patient self-satisfaction scores were subjectively graded using a visual analog scale ranging from 0 (excellent) to 10 (poor). Results: One surgeon performed each septoplasty using the same method; 2 (6.7\%) patients underwent additional valvuloplasty. The median scores in subjective satisfaction for the 30 patients were $8.4 \pm 1.22$ before surgery and $2.07 \pm 1.26$ after surgery $(\mathrm{p}<0.05)$. Furthermore, no patient experienced a saddle deformity, septal hematoma, septal perforation, or loss of nasal tip support during follow-up. Conclusions: After horizontal dorsal resection from the upper lateral cartilage during septoplasty, the patients experienced no stability problems. This suggests that this surgical technique is a safe and effective method for correcting high deviation due to a crooked dorsal septum.
\end{abstract}

\section{Hosted file}

Main Document.docx available at https://authorea.com/users/436564/articles/538794-horizontaldorsal-resection-of-a-crooked-septum-in-septoplasty

\section{Hosted file}

Figures.docx available at https://authorea.com/users/436564/articles/538794-horizontaldorsal-resection-of-a-crooked-septum-in-septoplasty

\section{Hosted file}

Table. 1.docx available at https://authorea.com/users/436564/articles/538794-horizontaldorsal-resection-of-a-crooked-septum-in-septoplasty

\section{Hosted file}

Table. 2.docx available at https://authorea.com/users/436564/articles/538794-horizontaldorsal-resection-of-a-crooked-septum-in-septoplasty

\section{Hosted file}

Table. 3.docx available at https://authorea.com/users/436564/articles/538794-horizontaldorsal-resection-of-a-crooked-septum-in-septoplasty 